\title{
Efficacy of Sakacin on Selected Food Pathogenic Microorganisms Isolated from Fermented Milk Products
}

\author{
${ }^{* 1}$ MOHAMMED, SSD., ${ }^{3}$ DAMISA, D., ${ }^{2}$ BALOGU, TV; ${ }^{2}$ BALA, E \\ ${ }^{I}$ Department of Microbiology, Faculty of Science, Kaduna State University, Kaduna, Kaduna State \\ ${ }^{2}$ Department of Microbiology, Faculty of Natural Science, Ibrahim Badamasi Babangida University, Lapai, Niger State \\ ${ }^{3}$ Department of Microbiology, School of Life Science, Federal University of Technology, Minna, Niger State \\ Corresponding author: mosada78@yahoo.com, Tel.+234(0)8035861774
}

\begin{abstract}
The efficacy of sakacin on selected food pathogenic microorganisms isolated from fermented milk products was investigated. The $L$.sake was isolated using the pour plate technique and was characterized based on it colony, cell morphology and some biochemical tests. This isolate was identified using standard scheme. The L sake FCF 33 was propagated in De Man Rogosa Sharpe (MRS) broth for bacteriocin (sakacin) production. The sakacin had inhibitory effects on all test microorganisms (ranging from $+5 \mathrm{~mm}$ to $+6 \mathrm{~mm}$ ) except Shigella dysenteriae N11, Salmonella typhimurium N8, Klebsiella ozaenae W24 and Proteus mirabilis N16a). Bacteriocins are antimicrobial substances of lactic acid bacteria (LAB) have gained tremendous attention as potential bio preservatives in the food and dairy industries. The LAB can serve as probiotics, which are products aimed at delivering living, potentially beneficial bacterial cells to the gut ecosystem of humans and other animals. (C) JASEM
\end{abstract}

http://dx.doi.org/10.4314/jasem.v20i1.12

KEY WORDS: Inhibition, sakacin, De Man Rogosa Sharpe, broth, morphology

\section{INTRODUCTION}

Fermented corn flour or starch (also called Akamu, Ogi) is prepared by first cleaning the cereal grain (Zea mays) and steeped in water for two days in earthenware pot (or any suitable container). The water is decanted and the grains wet-milled before sieving with muslin cloth or a fine wire mesh. The pomace is then discarded and the starch suspension is allowed to sediment during which fermentation is carried out for 2-3 days by the natural flora of the grains (Odunfa, 1985). Ogunbawo et al.(2003) isolated lactic acid bacteria from Ogi. The LAB isolated included Lactobacillus fermentum, Lactobacillus casei, Lactobacillus plantarum, Lactobacillus brevis and Lactobacillus reuteri for bacteriocin production.

Lactic acid bacteria are often inhibitory to other microorganisms and this is the basis of their ability to affect the keeping quality and safety of many food products. The principal factors, which contribute to this inhibition, are low $\mathrm{pH}$, organic acids, bacteriocins, hydrogen peroxide, ethanol, nutrient depletion and low redox potential. By far, the most important are the production of lactic acid and acetic acid and the consequent decrease in $\mathrm{pH}$ (Adams and Nicolaides, 1997). Lactic acid bacteria provide protection against spoilage microorganisms by producing varieties of antimicrobial compounds, including bacteriocins and also due to $\mathrm{pH}$ decrease and competition for substrates. LAB produce various compounds such as organic acids and bacteriocin during lactic acid fermentation ( Mohammed, 2015).
The potential application of bacteriocins as consumer friendly bio preservatives either in the form of protective cultures or as additives is significant. Lactic acid bacteria are typically in a large number of spontaneous foods fermentations but they are also closely associated with the human environment. Bacteriocins from the GRAS LAB, have received significant attention as a novel approach to the control of pathogens in foods (Settani et al., 2005).

The discovery of nisin, the first bacteriocin used on a commercial scale as a food preservative, dates back to the first half of this century (Saranraj et al., 2011), but research on bacteriocins from LAB has expanded in the last 20 years, prompted by their potential application as natural food preservatives and/or as food grade markers for the development of cloning vectors (Saranraj et al., 2011). Soomro et al. (2002) and Kacem et al.(2005) had identified and characterized bacteriocins produced by Lactococcus lactis sub sp. lactis ATCC11454, Pediococcus pentosaceus FBB61, Pediococcus acidilactici H, Leuconostoc gelidyn UAL187, Lactobacillus helveticus 481 and Camobacterium piscicola LV17 as Nisin, pediocin A, Pediocin AcH, Lecucocin, Helveticin $\mathrm{J}$ and Camobacteriocin repectively. Similarly Mohammed (2015) revealed that the largest spectrum of inhibition of microorganisms in that study was exhibited by bacteriocin (nisin) produced by L. lactis FMB14, FCF13 and FALB18 which inhibited all the test microorganisms in that study. This study is aimed at investigating the efficacy of 
sakacin on selected food pathogenic microorganisms isolated from fermented milk products.

\section{MATERIALS AND METHODS}

Collection of Samples: Samples of fermented corn flour were purchased from Bosso Market, Niger State, Nigeria and stored in sterile bottles. The fermented corn flour samples were immediately transferred to the Laboratory for the Isolation of lactic acid bacteria. Fermented milk (nono) and white cheese (wara) were also collected aseptically for isolation of test microorganisms.

Culture Media : The culture media used in this research were prepared following the standard laboratory methods as prescribed by Cheesebrough (2003). The media used in this study include), Urea agar base (Analar), Nutrient agar (NA) (Oxoid, Simon's citrate agar (Oxoid), De Man Rogosa sharpe (MRS) broth (Oxoid), Mannitol salt agar (MSA) (Oxoid) and Lactic Acid Medium (LAM) (Oxoid). Lactic acid bacteria medium (LABM) is a selective medium for the growth of lactic acid bacteria.

Isolation of Lactic Acid Bacteria (LAB): Twenty five grams $(25 \mathrm{~g})$ of fermented corn flour were aseptically transferred into sterile conical flask and $225 \mathrm{ml}$ of buffered peptone water, were added to obtain 1:10 dilution. The sample were blended for 1 minute respectively. $1 \mathrm{ml}$ of serial dilution of the sample was done in $0.1 \%$ peptone water. Serially diluted sample was placed on lactic acid Bacteria medium (LABM) and incubated at $37^{\circ} \mathrm{C}$ for 24 hours. Colonies that appeared on the plates were counted using the colony counter (Stuart, 6339, Co. Ltd. Great Britain) and the result recorded as colony forming units per gram (cfu/g). Pure culture was obtained by sub-culturing of the isolate on fresh media. Pure culture was maintained on agar slant for further characterization and identification ( Cheesbrough, 2003., Oyeleke and Manga, 2008).

Isolation of Test Organisms from Milk Products: Streak method of isolation described by Cheesbrough. (2003) and Bromberg et al. (2004) were used. Microorganisms were isolated from nono and wara. Sterile wire loop (heat to red hot, then allowed to cool) was used to pick samples from the blended wara samples. The samples were streaked on nutrient agar and incubated at $37^{\circ} \mathrm{C}$ for 24 hours. For the nono samples, sterile wire loop was dipped into the serially diluted samples and streaked on nutrient agar for each sample respectively and incubated at $37^{\circ} \mathrm{C}$ for 24 hours. The colonies that appeared on the medium were maintained on agar slants for further characterization and identification.

Characterization and Identification of Microbial Isolates: The LAB was characterized and identified based on colony morphology, cell morphology and biochemical tests (Fawole and Oso, 1998; Cheesbrough, 2003; Oyeleke and Manga, 2008). The biochemical tests include Gram's reaction, ammonia from arginine, carbohydrate utilization profiles, motility, production of catalase, coagulase, oxidase, citrate utilization, , mannitol activity, gelatine liquefaction, Indole test. The LAB was identified as Lactobacillus sake FCF 33 using the scheme of Begey's manual of determinative bacteriology (1984).

Screening of Lactobacillus sake FCF 33 for potential to produce Sakacin for Efficacy Studies: The Lactobacillus sake FCF 33 was selected based on its potential bacteriocin (sakacin) production in MRS broth using the methods described by Kacem et al. (2005). The sakacin was adopted from our previous research work (Mohammed, 2015).

Purification and Characterization of Sakacin : The methods described by Kacem et al. (2005) was employed in the purification process of sakacin FCF33 while the methods described by Soomro et al.(2002) and Ogunbanwo et al.(2003) were used in the characterization of sakacin .The sakacin was adopted from our previous research work (Mohammed, 2015).

Inhibitory Effects of Sakacin on Test Isolates: Well assay procedures of Kacem et al. (2005) were used. Aliquots of $500 \mu \mathrm{l}$ from each sakacin (bacteriocin) was placed in agar wells (the wells were bored using $5 \mathrm{~mm}$ cork borer) in Petri dishes seeded with the bioassay strains (Escherichia coli N2, Pseudomonas aeruginosa N7,Listeria monocytogenes W6,Shigella dysenteriae N11, Bacillus cereus W18,Salmonella typhimurium N8, Escherichia coli W4, Proteus vulgaris W7,Klebsiella aerogenes N12,Staphylococcus aureus N16b, Bacillus subtilis N20,Klebsiella ozaenae W24,Proteus mirabilis $\mathrm{N} 16 \mathrm{a})$ and incubated overnight at $37^{\circ} \mathrm{C}$ (anaerobically) and the diameters of the zone of inhibition was measured. The antimicrobial activity of the bacteriocins produced was defined as the reciprocal of the highest dilution showing inhibition of microorganisms multiplied by 100 and it is expressed as activity units per $\mathrm{ml}$ (AU/mL) (Ogunbanwo et al.,2003).

\section{RESULTS AND DISCUSSION}

The fermented corn flour analyzed had different species of lactic acid bacteria (LAB) in them. Lactobacillus sake FCF 33 was isolated and identified to specie level (Table 1). The Lactobacillus sake FCF 33 was selected after vigorous screening based on it ability to grow in De Man Rogosa Sharpe broth to produce sakacin, also through spectrophotometric analysis at $580 \mathrm{~nm}$ wave length, ${ }_{\mathrm{p}} \mathrm{H}$, bacteriocin activity $(\mathrm{AU} / \mathrm{mL})$ and with potential for use as food preservative. It was observed that Lactobacillus sake FCF 33 had growth ability of 
0.80 , at ${ }_{\mathrm{P}} \mathrm{H}$ of 3.90 and bacteriocin activity of $5400 \pm 0.00^{\mathrm{a}} \mathrm{AU} / \mathrm{mL}$ and was significant $(p>0.05)$ (Table 2).The sakacin had inhibitory effects on all test organisms (ranging from $+5 \mathrm{~mm}$ to $+6 \mathrm{~mm}$ ) except Shigella dysenteriae N11, Salmonella typhimurium N8, Klebsiella ozaenae W24 and Proteus mirabilis $\mathrm{N} 16 \mathrm{a})$.This could be as a result of the penetration ability/potential of the sakacin on the cell membranes of the cell causing efflux of amino acids and cations. Loss of these substances depletes proton motive force (PMF), which ultimately interferes with cellular biosynthesis. These events result in collapse of the membrane potential and ultimately cause cellular death of the test isolates (microorganisms) (fig.1).

Table 1.Cultural and Biochemical Characteristics of bacteriocin producing lactic acid bacteria isolated from Fermented Corn Flour

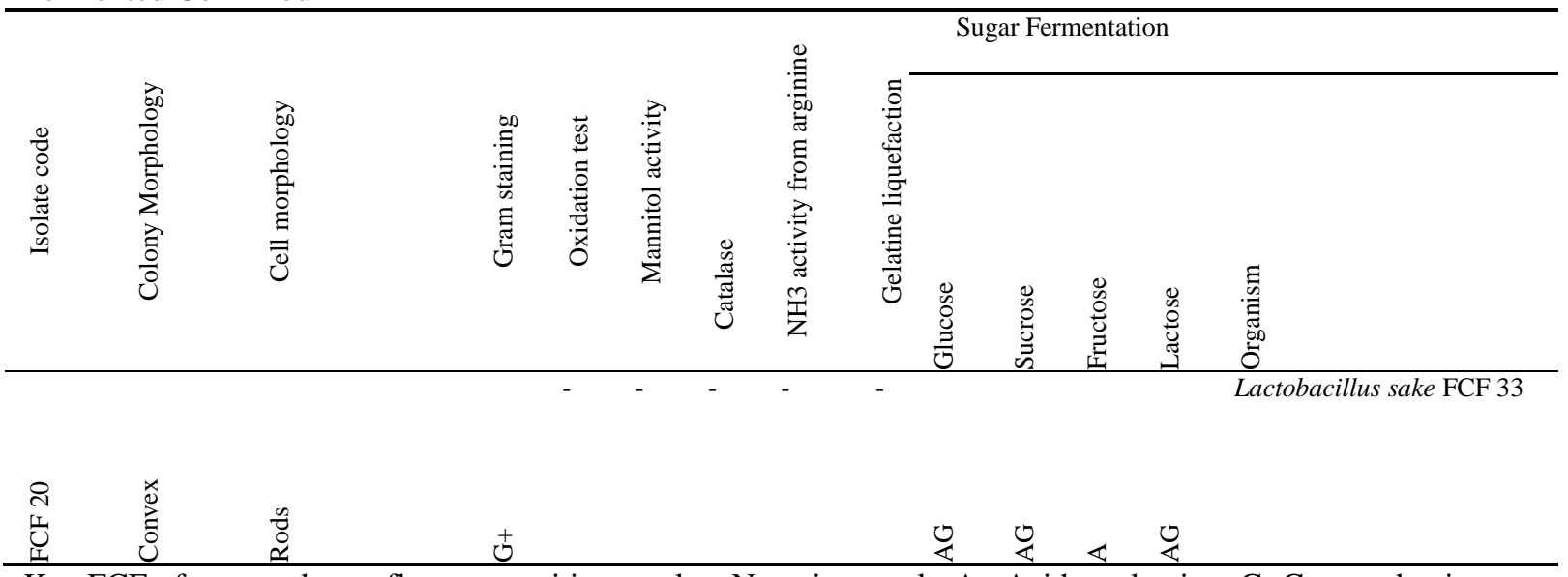

Key FCF : fermented corn flour,+ : positive result,-: Negative result, A : Acid production , G :Gas production, $\mathrm{AG}$ :Acid and Gas production, G+ = Gram positive.

Table 2.BacteriocinProducing Ability of Lactobacillus sake FCF 33

Code isolate Concentration $(580 \mathrm{~nm})$ $\mathrm{pH}$ of medium Bacteriocin activity $(\mathrm{AU} / \mathrm{mL})$

$\begin{array}{llll}\text { Lactobacillus sake FCF } 33 & 0.80 & 3.90 & 5400 *\end{array}$

FCF: fermented corn flour, AU/mL: Activity unit per millilitre, nm: nanometre*: potential bacteriocin producer.

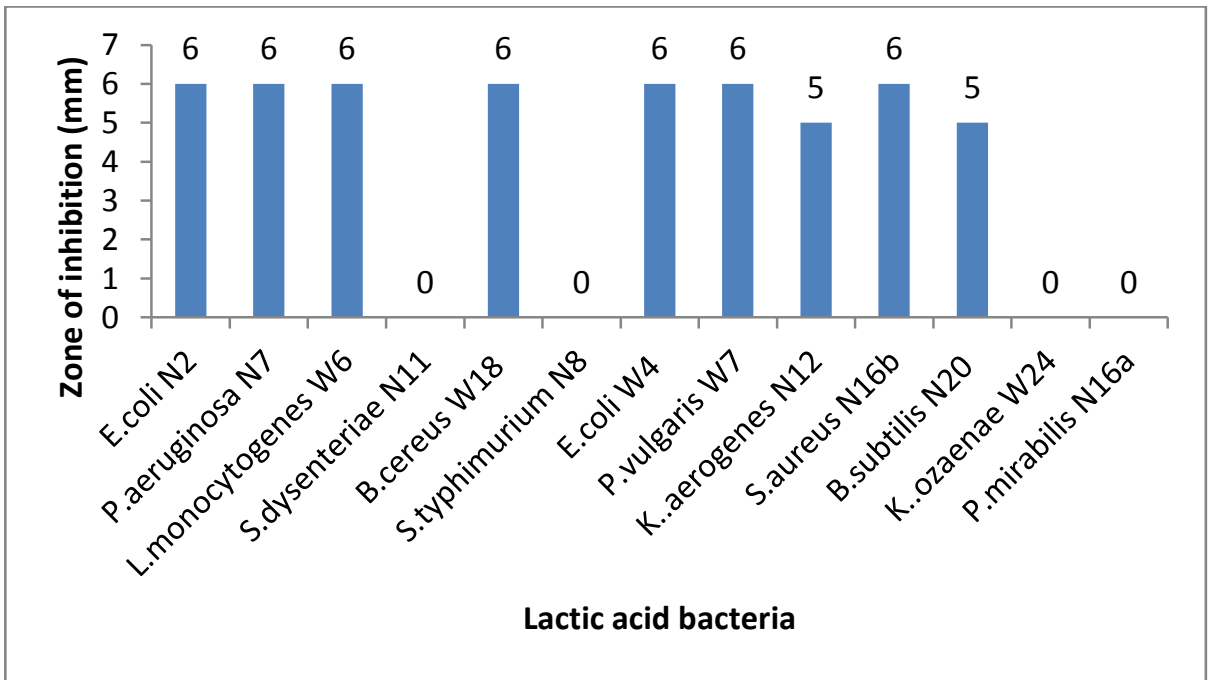

Fig. 1: Efficacy of Sakacin produced by Lactobacillus sake FCF 33 against Test Microorganisms

The fermented corn flour examined revealed the presence of different lactic acid bacteria (LAB) but Lactobacillus sake FCF 33 was of the study interest. The presence of LAB in locally fermented foods were previously reported by Oyeleke et al. (2006) who worked on occurrence of lactic acid bacteria in some locally fermented foods and reported frequent isolation of L. bulgaricus and L. acidophilus with $29 \%$ each of occurrence, followed by $S$. thermophilus (25\%), S. cremoris $(10.6 \%)$ and L. lactis $(6.4 \%)$ products. The present results is in conformity with the report of Mohammed and Ijah (2013) who worked on isolation of lactic acid bacteria (LAB) from yoghurt, cheese (wara) and fermented milk (nono) and 
revealed that out of fifteen samples analysed, thirteen $(86.6 \%)$ harboured LAB. Nono had the highest LAB counts $\left(9.8 \times 10^{6} \mathrm{cfu} / \mathrm{ml}\right)$ while yoghurt had the lowest LAB counts $\left(3.1 \times 10^{6} \mathrm{cfu} / \mathrm{ml}\right)$. The spectrum of inhibition of microorganisms in this study exhibited by sakacin produced by $L$. sake FCF 33 showed that it inhibited all the tested microorganisms (Escherichia coli N2,Pseudomonas aeruginosa N7, Listeria monocytogenes W6, Bacillus cereus W18, Escherichia coli W4, Proteus vulgaris W7, Klebsiella aerogenes N12, Staphylococcus aureus N16b and Bacillus subtilis N20) except Shigella dysenteriae N11, Salmonella typhimurium N8, Klebsiella ozaenae W24 and Proteus mirabilis N16a used in this study . This agrees with earlier reports by Sanni et al. (1999) and Deaschel (2011) and that some bacteriocins produced by gram-positive bacteria have broad spectrum activities against the test isolates used in the study. However, it was generally observed that bacteriocins from the producer organisms had no inhibitory effects on the organisms (LAB) producing it due to it self- defence mechanism. Similar observations have been made by Chavan and Riley (2007) that a typical bacteriocin contains a toxin (bacteriocin) gene, an immunity gene which confers resistance to the aforementioned toxin and a lysis gene, which encodes a protein that aids in toxin release from the producing cell. This is also similar to the report of Cotter et al.,(2006) who revealed that class II bacteriocins kill some pathogenic bacteria such as Listeria with high efficiency. Class IIa bacteriocin include Pediocin PA-1, Mesentericin Y105, Carnobacteriocin $\mathrm{B}_{2}$, Sakacin P, Enterocin A, Enterocin P, Leucocin A, Curvacin A and Listeriocin A. Class IIb becteriocins form pores in the membranes of target cells and distrupt the proton gradient of target cells.

Conclusion: The sakacin inhibited the growth of most of the spoilage and pathogenic microorganisms employed in this study. The use of bacteriocinproducing strains of LAB are of great interest as they are generally recognized as safe organisms and their antimicrobial products (bacteriocins) as biopreservatives. Bacteriocins are useful in biopreservation of food products, this is to improve the shelf life and safety of such food products.

\section{REFERENCES}

Adams M.R. and Moss, M.O. (2008).Food Microbiology. Royal Society of Chemistry, $3^{\text {rd }}$ edition,Cambridge CB4 OWF,UK.www.rsc.org. pp. 254-287.

Adams, M. R. and Nicolaides, L. (1997).Review of the Sensitivity of Different Food borne Pathogens to Fermentation Food Control, U.K.
Bergey's Manual of Determinative Bacteriology (1984). Krieg, N (Ed): (1 and 2) Williams and Wilkins, Baltimore.

Bromberg, R.(2004). Isolation of Bacteriocinproducing Lactic acid bacteria from meat products and it spectrum of inhibitory activity. Brazilian Journal of Microbiology. 35.(1-2).

Chavan, M.A. and Riley, M.A.(2007). Molecular Evolution of Bacteriocins in Gram-Negative Bacteria, In:Bacteriocins: Ecology and Evolution, Riley, M.A., Chavan, M.A. (Eds.). Heidelberg, Germany. pp.5-18.

Cheesebrough, M. (2003).District Laboratory Practices in Tropical Countries. Cambridge University Press, Edinburgh, Uk. pp. 382-407.

Daeschel, M.A. (2011).Antimicrobial substances from Lactic acid bacteria for use as food preservatives. Journal of Food Preservatives, 44, 164-167.

Fawole, M.O. and Oso, B.A. (1998) Laboratory Manual of Microbiology. Spectrum book limited, Ibadan, Nigeria, pp $16-35$.

Kacem, M., Zadi-Karam, H and Karam, N.(2005). Detection and activity of plantaricin OL15 a bacteriocin produced by Lactobacillus plantarum OL15 isolated from Algerian fermented olives. Grasasy Aceites.56 (3) :192197

Mohammed,S.S.D.(2015).Optimized production of bacteriocins from lactic acid bacteria for Biopreservation of fermented milk (Nono) and white cheese (Wara). Unpublished Doctoral (Ph.D) Thesis, Federal University of Technology, Minna, Nigeria. pp $4-150$.

Mohammed,S.S.D., Damisa, D.,Oyeleke,S.B., Jigam, A.A.(2013).Biopreservation Studies of White Cheese (Wara) using Acidophilin produced by Lactobacillus acidophilus FCF2 isolated from Fermented Corn Flour. Journal of Engineering and Applied Sciences: 2(1), pp1-9.

Mohammed,S.S.D and Ijah ,U.J.J. (2013).Isolation and Screening of Lactic Acid Bacteria from Fermented Milk products for Bacteriocin Production.Food Microbiology and safety:Annals.Food Science and Technology.14 (1):122-128.

Mohammed,S.S.D.(2012). Production, Purification and Characterization of Bacteriocins Produced by Lactic Acid Bacteria isolated from fermented foods. Fellowship (FISLT) Thesis, Nigerian 
Institute of Science Laboratory Technology (NISLT). Ibadan, Nigeria. pp 59-61.

Odunfa, S.A. (1985). African fermented foods. In: B.J.B. Wood, (ed.) Microbiology of Foods. Elsevier, London.pp. 155-191.

Ogunbanwo, S.T., Sanni, A. I. and Onilude, A.A. (2003).Influence of cultural conditions on the production of bacteriocin by Lactobacllus brevis OG1.African Journal of Biotechnology, 7: 179 184.

Oyeleke, S.B. Faruk, A.K.,Oyewole, O.A. and Nabara, HY. (2006). Occurence of Lactic acid bacteria in some locally fermented food products sold in Minna markets. Nigerian Journal of Microbiology, 20 (2): 927-930.

Oyeleke, S.B. and Manga, B.S. (2008).Essentials of Laboratory practicals in Microbiology (first edition).Tobest publishers, Minna, Nigeria, pp, 28- 62 .

Sani A.I, Onilude, A.A., Ogunbanwo, S.T. and Smith, S.I. (1999) Antagonistic activity of bacteriocin produced by Lactobacillus species from Ogi, an indigenous fermented food. Journal of Basic Microbiology,39:189-195.
Saranraj, P ., Naidu, M.A. and Sivasakthivelan, P.(2013). Lactic Acid Bacteria and its Antimicrobial Properties:A Review. International Journal of Pharmaceutical and Biological Archives. 4(6), 1124 $-1133$.

Savadogo, A., Ouattara, C. A.T., Bassole, I. H. N., Traore, S. A. (2006).Bacteriocins and lactic acid bacteria - a minireview.African Journal of Biotechnology.5 (9): 678-683.

Settani, L., Massitti, O., Van Sinderen, D. and Corsetti, A. (2005). In situ activity of a bacteriocin - producing Lactococcus lactis strain. Influence on the interactions between lactic acid bacteria during sourdough fermentation. Journal of Applied Microbiology.99, 670-681.

Sharma N, Kappor G and Neopaney, B. (2006). Characterization of a new bacteriocin produced from a novel isolated strain of Bacillus lentus NG121. Antonie Van Leeuwenhoek 89:337-343.

Soomro, A.H., Masud, T. and Anwear, (2002).Role of lactic acid bacteria in food preservation and human health.Pakistan Journal of Nutrition, 1(1): $20-24$. 